\title{
The political ecology of voice (PEV); an innovative approach to examining environmental pollution and the accountability of economic actors
}

\author{
Adrian Gonzalez ${ }^{1}$ \\ Royal Holloway, University of London, UK
}

\begin{abstract}
In this article, I use Albert Hirschman's consumer-based 'exit' and 'voice' concepts in order to set out the political ecology of voice (PEV), an innovative theoretical framework that aims to examine the causes of environmental pollution from a new angle. I begin by providing a brief overview of political ecology, and why it provides such a useful framework from which to position Hirschman's ideas of exit and voice. This will lead into a more detailed analysis of Hirschman's theories in an environmental context, and why the use of voice by various stakeholders (citizens, community based organizations (CBOs) and nongovernmental organizations (NGOs)) is dependent upon a number of political, economic, social and geographical factors over a specific temporal period. The study of voice through PEV will enable researchers to examine the accountability of economic actors for incidents of environmental pollution.
\end{abstract}

Keywords: Albert Hirschman, political ecology of voice

\section{Résumé}

Dans cet article, je utiliser les concepts de la sortie (exit) et la voix (voice) d'Albert Hirschman afin de définir l'écologie politique de la voix $(\mathrm{PEV})$, un cadre théorique novateur qui vise à examiner les causes de la pollution de l'environnement à partir d'un nouvel angle. Je commence par donner un bref aperçu de l'écologie politique et pourquoi il offre un tel cadre utile pour positionner les idées de Hirschman de la sortie et de la voix. Cela nous mène à une analyse plus détaillée des théories de Hirschman dans ce contexte environnemental. Je examine l'utilisation de la voix par les parties prenantes (citoyens, les organisations communautaires de base (OCB), et les organisations non-gouvernementales (ONG)). Son utilisation est tributaire d'un certain nombre de facteurs politiques, économiques, sociales et géographiques sur une période de temps spécifique. L'étude des voix à travers PEV permet aux chercheurs d'examiner la responsabilité des acteurs économiques pour les incidents de pollution de l'environnement.

Mots-clés: Albert Hirschman, l'écologie politique de la voix

\section{Resumen}

En este artículo utilizo los conceptos de Albert Hirschman de "salida" y "voz" para desarrollar una "ecología política de la voz" (PEV por sus siglas en inglés), y examinar desde esa perspectiva las causas de la contaminación ambiental. Empiezo con una revisión de la literatura sobre ecología política, y explico porque ese acercamiento teórico beneficia de la integración de los conceptos de ?salida? y ?voz? de Hirschman. Sigo con un detallado análisis de las teorías de Hirschman en un contexto ambiental, y discuto porque el uso de ?voz? por parte de interesados tales como ciudadanos, organizaciones basadas en la comunidad y organizaciones no gubernamentales depende de varios factores políticos, económicos, sociales y geográficos durante un tiempo determinado. El estudio de ?voz? desde la perspectiva de la PEV ayuda identificar la responsabilidad de los actores económicos para la contaminación ambiental.

Palabras clave: Albert Hirschman, ecología política de la voz

\footnotetext{
${ }^{1}$ Adrian Gonzalez, PhD student, Department of Geography, Royal Holloway, University of London, UK. Email: Adrian.Gonzalez.2013 "at" live.rhul.ac.uk. Thankvou to the JPE editors and referees and mv supervisor, Professor David Simon. Research was funded by a Royal Holloway Irene Marshall Scholarship and a Royal Holloway Geography Department Paul Broome Award.
} 


\section{Introduction}

The causes and consequences of environmental pollution are numerous. In a broad sense, pollution can be caused by industrial operational failures, mismanagement or poor standards, weak environmental regulation at various spatial levels (local, national, regional, international) and economic influences, to name but a few. Our understanding of these factors rests on our ability to engage with the intricate, often inter-connected processes that lie behind the pollution problem, a target most readily achieved through solid theoretical and methodological foundations. Work identified with post-ecologism (Bluhdorn and Welsh 2007), environmental racism (Bullard 1993) and ecological distribution conflicts (Martinez-Alier 2004), has begun to do this.

This article aims to build on existing research and the understanding of pollution problems through the presentation of an innovative approach termed 'the political ecology of voice' (PEV), which combines a political ecology framework with the theory of voice developed by Albert Hirschman. PEV can be defined as the study of a specific temporal, economic, social, and geographical environment in which various stakeholders (e.g. citizens, community based organizations (CBOs) and non-governmental organizations (NGOs)) utilize their voice over an environmental issue. PEV is able to draw together these temporally influenced factors and, taken together, it forms a comprehensive theory also capable of influencing stakeholders and holding economic actors to account for pollution.

A study of voice from an environmentally based context, its application, the influences upon it and the feasibility of success are not new research strands. Studies surrounding the theme of voice include exploring community-based natural resource management (Agrawal and Gibson 1999), participatory relationships between managers and local people in environmental and developmental situations (Bixler et al. 2015), governance interactions between actors involved in environmental management (Andersson 2004), efforts by local communities to gain access and power over natural resource management (Boelens et al. 2010) and the process of negotiation between companies and communities (Le Meur et al. 2013). In some areas, particularly research examining participatory approaches, there are clear similarities with voice through its efforts at understanding the level and nature of engagement (Bixler et al. 2015) between various actors and the study of the opportunity of individual freedom in pursuit of developmental outcomes (Sen 2001). However, the generalized nature of these theories requires greater placement within institutional and environmental histories (Bixler et al. 2015: 177). A stronger theoretical framework can examine these influences and their impact on participation. PEV offers one such approach. In other studies, voice-related issues would appear to emerge out of other investigatory themes (Hinojosa et al. 2015: 111-112) or through the application of different theoretical perspectives (Le Meur et al. 2013 on diffusion processes), making voice appear to be a by-product of other influences. This should by no means be seen as criticism of existing research, which has been vital to help improve our understanding of the difficulties of environmental management, the relationship and interaction between actors and the implications of poor governance.

Through PEV, the study of voice can become an explicitly stated aim of research, strengthened through a theory that can help researchers map out and understand the complexities surrounding the application of voice, retain analytical focus on voice, and examine its placement within institutional and environmental histories. By doing so, it is hoped that this innovative theoretical approach will help improve our understanding of the causes of environmental pollution.

The first section of this article outlines the academic school of political ecology and why voice can be sited so successfully within it. This is followed by an exploration into Hirschman's theories and why voice can also be integrated into an environmental context. The final section explores how the contextual influences surrounding the application of voice by citizens can be combined with certain aspects of political ecology (power, space and time) in order to form PEV. The arguments are illustrated through secondary-sourced examples taken from different parts of the world in order highlight how the approach is relevant for the study of different pollution-based scenarios. 


\section{Political ecology}

We consciously seek to avoid disciplining political ecology....To the contrary, we encourage the flourishing of political ecology to include the fullest possible range of approaches. (Zimmerer and Bassett 2003: 2)

Political ecology has been described and used in so many different ways that according to some commentators, it has little overlap in meaning (Biersack 1999: 11; Newman 2005: 3) and the range of approaches and modifiers to the term testify to this argument (Blaikie and Brookfield 1987a; Bryant 2015a; 1992; Bryant and Bailey 1997; Forsyth 2003; Perreault et al. 2015). Despite its flexibility as an analytical perspective or framework, there are a number of visible starting points which provide a degree of coherence to the field while still leaving space for exploration (Neumann 2005: 10). A foray into political ecology not only highlights the academic space available to site PEV but more importantly reveals that many of its interlinked elements offer striking integration with Hirschman's theory of voice.

The term political ecology is constructed "through the merger of cultural ecology with political economy" (Blaikie and Brookfield 1987a: 17), the latter utilised in a broad sense (Newman 2005: 9; Watts 2015) and in this article can be understood "...to refer in general terms to the politics of environmental problems without specific focus on the ecology" (Forsyth 2003: 4). Within secondgenerational political ecology, important consideration is given to political, economic and social structures and their institutions, and how these impact the human construction, transformation and management of already humanized 'natural' ecosystems (Blaikie 1985; Blaikie and Brookfield 1987a; 1987b; Bryant and Bailey 1997; Ioris 2011; Newmann 2005; Peet et al. 2011; Watts 2015: 32-34). From this broad premise, there are a number of elements that need greater analysis owing to their significance for PEV.

A central aspect of contemporary political ecology has been its effort to establish a more complex understanding of the diverse nature of power and authority and how its relations define, facilitate, manage and control human-environmental interactions in differing environmental contexts such as resource extraction and land ownership (Batterbury 2015; Bridge 2011; Bryant 1998: 82-85; Neumann 2005). As Peet et al. (2011: 31) correctly identify, "...[e]nvironmental problems (and their possible solutions) are inevitably entangled with questions of power and governance" which has seen an academic focus on various actors including the nation-state (Ioris 2014), businesses (Bebbington et al. 2013) and non-state actors (Khan 2013).

Crucially however, these power relations are often unequal. This is apparent between business actors and their relationships with citizens (Cragg and Greenbaum 2002; Himley 2008) and thus become linked to conflicts over forms of access and control of natural resources and the implications these have for environmental health and sustainable livelihoods (Watts 2000: 257). A vital point is the relationship between economic actors like resource extraction industries (REIs) and citizens, and the extent to which the former can control and manage the latters' access to decision-making mechanisms surrounding natural resource management and environmental problems.

Similarly, citizens in their participatory relationship with NGOs can often struggle to hold these actors to account due to their lack of obvious accountability options. "Unlike donors, [communities] cannot withdraw their funding; unlike governments, they cannot impose conditionalities"' (Najam 1996: 346-347). They lack 'downward accountability' and power (O'Dwyer and Unerman 2010). Here again, thought must be given to the accountability and power relationships between these citizen and non-state actors and the way in which debates over environmental pollution and actions taken to combat it are framed.

Finally, inequality is also present in the utilization of power by the state. Its prioritization of industrial interests lends power to dominant economic actors and social groups at the expense of other groups whose interests will be marginalized if found to threaten those of the dominant group (Blaikie and Brookfield 1987a: 17; Nash and Lewis 2006). The state's diffusion of power, influence and access to specific social groups or actors influences how well citizens and civic or non-governmental organisations 
can hold industry or government accountable for pollution incidents. Political ecologists' research into the retention and use of power by the state is important, and highlighted in this article.

Power inequality is not the only factor that can limit individuals and collective group's efforts for environmental accountability. Political ecologists highlight how at a macro-level, individual choice and action are constrained by an array of spatial, economic, social and historical contextual forces (Lipschutz 1997: 88-91). Scale, place and time are important aspects of the political ecology framework.

Scale is important due to its relationship to power (a so-called "politics of scale", Watts 2000: 158) and is thus critical in efforts to identify the occurrence and causes of environmental degradation (Newmann 2005: 76). Of significance for this article is the possible impact that spatial power relations have on the accountability of environmental problems at the state-societal level. Research on the broad question of spatial power has been conducted by scholars who examine "frontiers" (Karlsson 2011) and "territories" (Greenberg 2006: 127-129; M'Gonigle 1999). Their conclusions are that the state imposes administrative and territorial hierarchies to control resources (Greenberg 2006: 127). Spatial-power dynamics often involve a concentration of power in the centre which leaves territorial power dispersed through social forms in "small villages, local markets and community halls, regions beyond the city" (M'Gonigle 1999: 17). This is a type of simplification for the purposes of state control (Karlsson 2011). A challenge for communities living in these spatially remote localities, particularly those on the peripheries of mainstream society who wish for greater rights or self-determination, is to overcome potential state reluctance to devolve and share power and to support scale-specific institutions (Silvern 1999: 665-666), an indication of the way that the operation of power maps "...social inequalities onto spatial categories" (Moore 1998: 351).

Consequently, one has to consider how much impact these spatial-power relations have on citizen access to state decision making mechanisms, especially for more remotely situated citizens located in places like the Amazon rainforest. Oil production sites, for example, are often remote and have the highest power densities (measured in Watts per square meter) of any natural energy or anthropogenic feature on earth (Cleveland 2007) with REI power coming from their "ability to control specific patches of ground" (Bridge 2011: 319). In remote geographical locations 'away' from the state, are state functions, and consultation and communication sites accessible for local people?

Lastly, tied to all of these discussions is an awareness that the relationship between political, economic, social, and spatial processes and their impact on the environment changes over time (Batterbury and Bebbington 1999: 281-282). A focus on past events like the progressive incorporation of emerging market and developing economies (EMaDE) into an advanced economy (AE) based system of capitalist production provides a crucial understanding for "...contemporary patterns of humanenvironmental interaction and associated power relations" (Bryant 1998: 85). This means political ecology is in part historical (Davis 2015). This historical acknowledgement is important given that some factors influencing environmental degradation are only visible over long periods of time (Batterbury and Bebbington 1999: 281), e.g. the effects of population pressure. The distribution of power changes markedly over time (see Silvern 1999: 644-645 for a United States example). The influence/power/position of people also changes - Hvalkof shows how the Peruvian Ashenika indigenous people "...underwent a metamorphosis" transforming from colonist exploited labour through to active political agents of social change and democratization (Hvalkof 2006: 197). Modern political ecology reflects this by recognizing the speeding of human ingenuity and technological transformations which have made nature unrecognizable (Berglund 2006: 99; Bryant and Bailey 1997: 5).

Overall, the focus on these various elements of political ecology (power, spatial location and time) reveal the most important areas that bear significant integration with Hirschman's theories in an environmentally based context. PEV, like political ecology can be seen to be borne from efforts to promote positive social and ecological change and justice (Bridge et al. 2015: 8; Bryant 2015b: 22) and to fight against the unjust ways in which politics, economics, culture and ecology come together and help cause environmental pollution (Bryant 2015b: 20). This next section of the article will set out how Hirschman's theory of voice offers integration with political ecology and the establishment of PEV. 


\section{Albert Hirschman's exit and voice, and reconceptualization in an environmental scenario}

Gaining voice is a struggle but so too is giving voice (Bryant 2015b: 23).

Albert Hirschman, a founding father of post-WWII development economics and one of the twentieth century's most influential economists, set out the theories of exit and voice in Exit, voice and loyalty: responses to decline in firms, organizations and states (1970). His ideas were subsequently reexamined (Hirschman 1995; 1982; 1981; 1978). As the title suggests, the book was centered on an investigation into the distinct consumer responses to a decrease in quality or benefit they perceive from a firm, organization or state.

The exit option will see consumers stop buying a firm's products or members leave an organization (Hirschman 1970). This can be neat ("one either exits or one does not" (Hirschman 1970: 15)), impersonal (where there is no face-to-face confrontation between customer and firm), indirect (a firm's recovery comes through the economic Invisible Hand as an unintended by-product of the customer's decision to shift suppliers (Hirschman 1970: 15-16)) and typically as a private, silent decision and activity (Hirschman 1995: 34). Voice on the other hand will see consumers or an organization's members express their dissatisfaction to those in question (Hirschman 1970: 4). Unlike exit, it is labelled as "messy" due to the different gradients that encompass voice ("all the way from faint grumbling to violent protest"), public ("implies articulation of one's critical opinions rather than a private "secret" vote in the anonymity of a supermarket...") and "direct and straightforward" (Hirschman 1970: 16).

Figure 1 provides a "rough summary" of organizations classified in relation to the absence or presence of exit and voice (Hirschman 1970: 120). Hirschman acknowledges that there are minimal cases where exit and voice both play important roles, but does proceed to highlight some examples in the top left hand corner of the diagram e.g. some business clients will attempt to influence firm policies directly (via voice) instead of choosing exit, though exit remains an option (Hirschman 1970: 121). In contrast, "[t]here are probably no organizations that are wholly immune to either exit or voice"; such organizations, as listed in the bottom right-hand corner of Figure 1, are likely to be less viable long-term (Hirschman 1970: 121). In this scenario, exit and voice will only be engaged when deterioration is so highly advanced that recovery is either impossible or desired (Hirschman 1970: 121). Despite this, the author makes clear that the former organizations (those equipped with exit and voice) are not necessarily more advanced that those which rely on one action. Rather, it is entirely dependent on the responsiveness of the organization and their ability to mobilize through exit, voice or both these mechanisms (Hirschman 1970: 121-122).

Outside of the consumer-industry scenario, exit and voice correlate with political and economic ideals for social change. Initially, Hirschman saw exit more closely aligned with consumer decisionmaking and hence with market forces acting, and voice responses involving political contestation and public actions (Hirschman 1970: 15; Hirschman 1982: 65), though he later acknowledged that these were not exclusive. ${ }^{2}$ Exit and voice responses have been widely analyzed in other contexts (Picciotto 2015: 1). ${ }^{3}$ I am concerned with applying them in a context of environmental contestation that can help us understand the possible difficulties that citizens may face in holding economic actors accountable for forms of pollution.

Exit or "distancing" (Zuindeau 2009: 155), can be especially problematic for citizens facing proximate environmental issues. Firstly, exit is tied closely to the idea of loyalty (see Figure 2), a concept similar to trust (Hirschman 1992: 80-81) and which "...marks the attachment of the individual or the group to a product, an organization, or a territory" (Zuindeau 2009: 156). However, there is a visible difference between loyalty to a product and loyalty to one's employer, family or tribe which can "...be thought of as a 'group' with which one identifies" (Dowding et al. 2000: 476). This distinction is important because 'group' loyalty is influenced by how much one has invested in the region, or object or organization over time (Dowding et al. 2000: 477). Group loyalty (especially if it is strong) may prevent

\footnotetext{
${ }^{2}$ On social exit see Hirschman 1981: 223; 1992: 78, 96. On consumer use of voice see Hirschman 1982: 65.

${ }^{3}$ See Flew 2009 in relation media citizenship; Lindell (2010) in relation to the African informal economy and street traders; Lucero (2008) on indigenous political representation in the Andes, and Ramana (2013) on nuclear policy.
} 
people exiting and distancing themselves from a particular location, e.g. a English person may feel strong loyalty to their country which nullifies the obvious choice of exit brought on by a deep disagreement with government policies (Dowding et al. 2000: 477). In the same way a family may be reluctant to leave their land despite a deteriorating environment, because it has been in their household for hundreds of years (Blaikie 1985: 26-27).

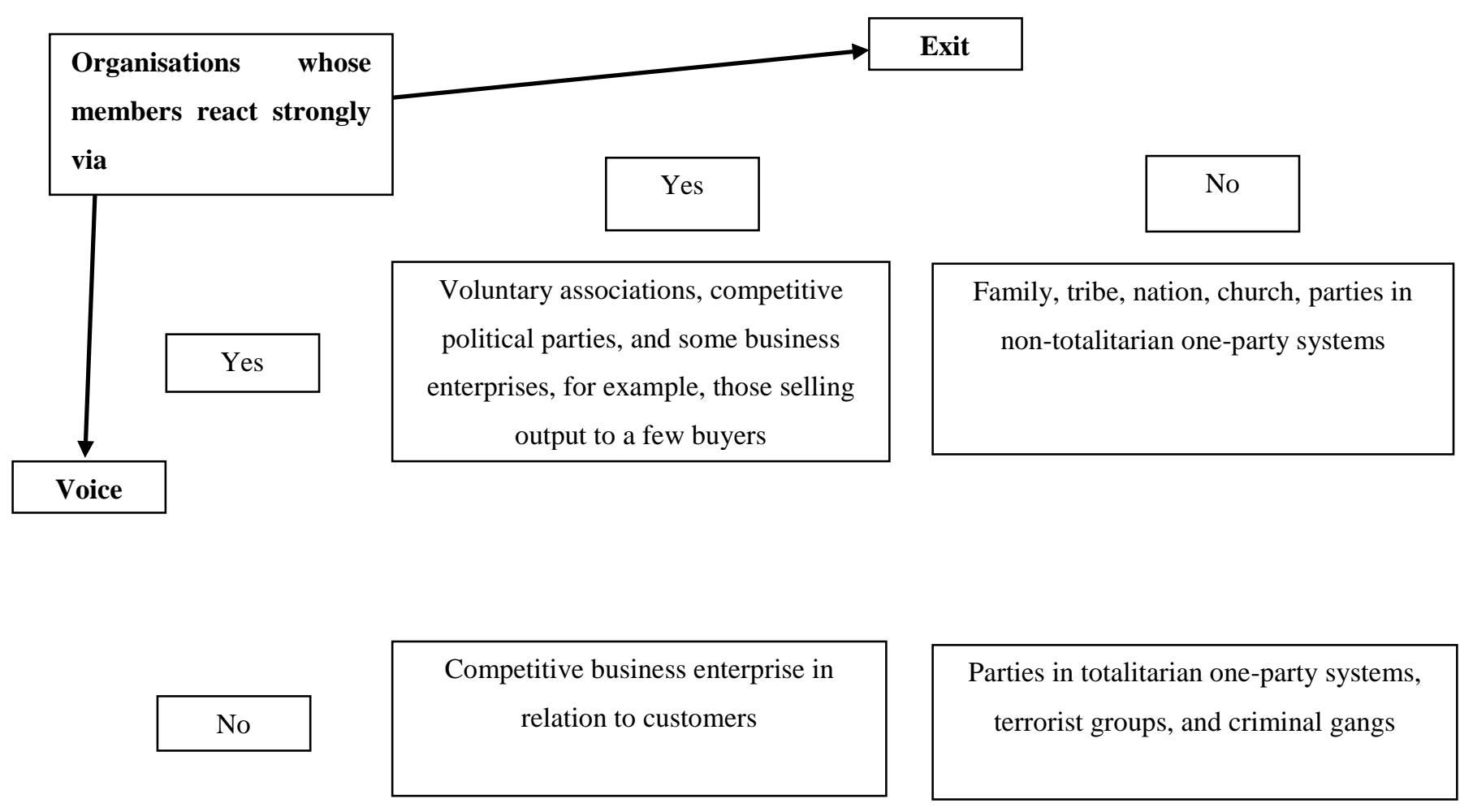

Figure 1: The elusive optimal mix of exit and voice (Hirschman 1970: 121).

The underlying influences for people's loyalty have been traced by authors like Groves (2015) and Zunideau (2009) who's focus on "attachments" and so-called "second variables" (the positive or negative complementarity between economic issues and environmental issues ${ }^{4}$ ) to explain why people can be unwilling to exit. Individuals and groups may have emotional attachments to their environment and particular location around them, incorporating inter-personal relationships and life-world attachments that are historical as well as social (Broto 2013: 4; Groves 2015: 5-6). A pollution event may see a person take into consideration their health and those of their family "...versus keeping quiet to defend his economic interests, even disputing the legitimacy of the critical voices of others" (Zuindeau 2009: 162). While distancing oneself from the problem is a solution, it then becomes a question of comparing the delocalization-relocalisation costs e.g. the well-being advantages and the economic costs (e.g. daily transport expenditure) caused by distance (Zuindeau 2009: 162).

\footnotetext{
${ }^{4}$ If the complementarity is positive, exit behaviour "will be high if one fears that the situation will deteriorate more, whereas it will be more limited if one expects that the situation will improve in the future (attitude of patience)." However, if the complementarity is negative but applies to others instead, the use of voice will be higher, but in positions where obstacles to voice are present (being a minority citizen for instance), the exit option is favoured (Zuindeau 2009: 162).
} 


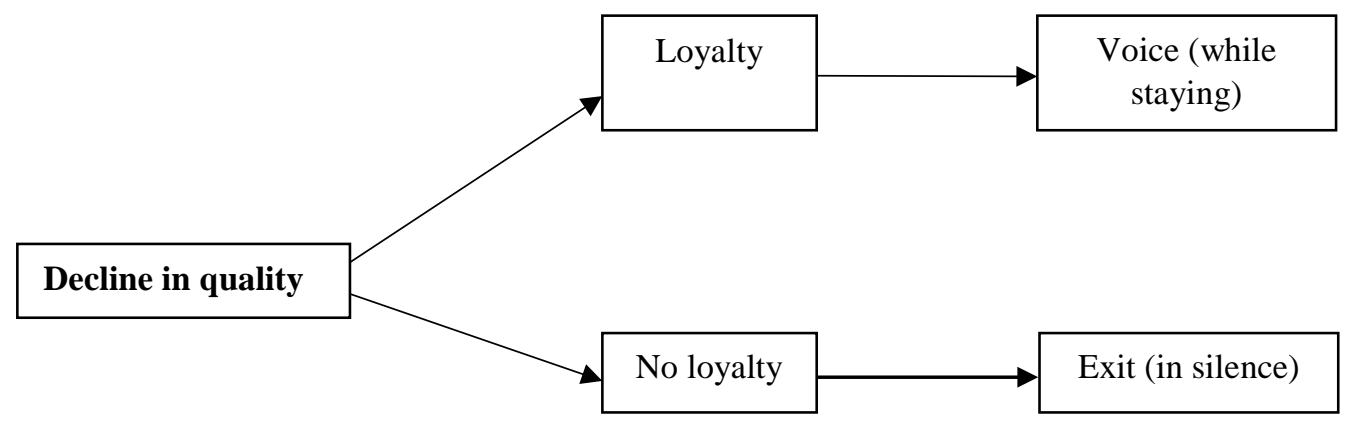

Figure 2: Birch's version of Hirschman's loyalty concept (Birch 1974: 73)

It is highly likely that strong attachment through a range of attachments to a given area and the physical world around a person/group will help to limit the use of exit from a negative environmental scenario (dependent on the temporal context, discussed shortly) and instead increase the use of voice. Therefore, these complex and wide ranging life considerations (social, economic and potentially spiritual and cultural, including ethnicity) will constrain citizen use of exit for an environmental problem. This is most acute for marginalized people or groups as exit is unavailable to some due to income and wealth (Hirschman 1978: 95-96). Indeed, the use of exit by people who can financially afford to do so allows it to become an example of the "tyranny of small decisions"'" as those exiting fail to take into account their responsibility to fight the infliction of a public bad on others (Hirschman 1992: 80 see also Hirschman 1981: 243; 1978: 96-101). One's private self-interest that may extend as far as one's family (Dobson and Bell 2006: 2; Rousseau 2012) but not to community. For some, this is a reflection of the dominance of the private sphere (work, home, family) in modern-day society over the public sphere and its "...practices of public service, citizen participation, loyalty to the community, and activity for the common good" (Barry 2006: 36-37).

The decision to exit has two consequences on voice. Firstly exit will "drive out" voice (Hirschman 1970: 76) or deprive its potential carriers (Hirschman 1995: 13) "in the sense that the 'alert' who may have voiced, exit instead, leaving behind the 'inert' who then suffer in silence" (Dowding 2000: 472), a situation Barry (1974: 91) labels "silent non-exit". ${ }^{5}$ Moreover, in affluent societies where privileged groups are seen to bear the greatest responsibility for taking action to combat the negative effects of their unsustainable lifestyles (Horton 2006: 128), exit can be labelled as a cop-out, an avoidance of their environmental responsibilities and the "politics of obligation" (Smith 1998). In an environmental pollution scenario, exit could see the continuation of pollution that could continue unchecked and/or affect other people that were unable to exit (so called "cumulative decline"; Hirschman 1992: 90). Zuindeaun (2009: 163) also suggests that the greater the geographic scope and magnitude of the problem, the more difficult it is to exit.

Secondly, Hirschman originally saw that consumer exit will often only be taken "in the light of the prospects for the effective use of voice" (Hirschman 1970: 37). If consumers are sufficiently convinced of the effectiveness of voice, they may postpone exiting, as by doing so they lose the opportunity of using their voice (Hirschman 1970: 105). The reverse does not occur (Hirschman 1970: 37). If this is combined with the influence of loyalty and real-world attachments, it would suggest that in an environmental pollution scenario, exit is an action of last resort, which is particularly true if one considers the temporal aspect of loyalty and voice. Loyalty will hold exit at bay and activate voice (Hirschman 1970: 78) due to time horizons (Broto 2013: 10; Graham and Keeley 1992: 198). It is unlikely that a citizen would abruptly relocate to a different location at the first sign of a environmental problem without first voicing concerns and allowing time for a solution to be implemented.

What can we conclude about exit in relation to an environmental pollution event? It would appear to be an action that is constrained by loyalty, which is itself influenced by a number of real-world attachments. Whilst it can be utilized by those with the means to do so, this can damage the voices of

\footnotetext{
${ }^{5}$ This conclusion is not applicable in all cases, however. See Birch (1974: 77) on public and private schools and the "exit plus voice" idea discussed by Barry (1974: 92).
} 
those left behind, and it fails to prevent the continuation of the pollution problem. Its relationship to voice can also be understood if one considers exit as an action of last resort, only taken by some after a period of time has elapsed in which the use of voice has failed to find a solution or when a person's loyalty and life attachments to their present location are weaker. One can already see that the consumer-industry voice scenario can be rethought and extended to account for the responses experienced to environmental problems.

In the original premise, consumers have different perceptions of the quality of products (Hirschman 1970: 48) which may impact upon their willingness to voice over issues with quality or supply. However, the situation in relation to citizens and the quality of the environment is very different. While voice was seen as a costly option for consumers (Hirschman 1970:40), the action will have an edge over the use of exit in situations that impinge on public interest (Hirschman 1982: 6-7) such as a food health hazard, an automobile safety problem (Hirschman 1981: 217) or conceivably an environmental problem. Indeed, the public interest surrounding the environment is clear; many governments now incorporate a right to a healthy environment in their constitutions while various branches of the UN have adopted similar positions (UN 2007; UN Mandate on Human Rights and the Environment). This reinforces the declaration that citizen's deserve "...adequate conditions of life, in an environment that permits a life of dignity and well-being" (United Nations Environment Programme 1972 Principle 1).

Moreover, for citizens themselves, the use of voice is extremely relevant for an environmental problem as "everyone has a strong motivation to defend the quality of life at his own station" (Hirschman 1970: 53). This issue will attract degree of public interest (dependent on the context, i.e. its severity), which will undoubtedly cause a strong degree of feeling over desired outcomes (i.e. an end to the pollution), that would help to outweigh the uncertainty that people may feel over participation (Hirschman 1981: 216; Zuindeau 2009). Thus, public participation through voice empowers citizens as they seek a stronger role in decisions that affect their lives (Zimmerman and Rappaport 1988, cited in Laurian 2004: 53).

Lastly is Hirschman's exploration of voice in political/public action scenarios. There is an 'individual' and 'collective' voice and there are 'horizontal' and 'vertical' voices, all of which are interlinked and which reinforce the connection between voice and environmental problems. The exploration of voice in a political/public action scenario highlights that the functioning of voice depends upon the "potential for collective action" (Hirschman 1992: 79) as opposed to a person's singular voice. ${ }^{6}$ This is linked to the division of voice between horizontal and vertical settings (Le Meur et al. 2013; O'Donnell 1986; Ravnborg and Gomez 2014). Horizontal voice refers to communication with other actors who share some form of collective identity at the same level whilst vertical voice refers to communication with actors at different levels of society, like government (O'Donnell 1986: 251; Ravnborg and Gomez 2014: 73) and other economic actors (e.g. REIs). Crucially it is most often collective in political situations (O'Donnell 1986). Horizontal voice can be more important than vertical voice owing to its necessity as a precondition for the latter (O'Donnell 1986: 251-252; Ravnborg and Gomez 2014: 73).

Environmental problems are most often dealt with through vertical political channels that lend themselves to the strengths of collective voice, made up of the 'pool' of people affected by pollution. Individuals faced with a vertical hierarchy know that they will not be able to "... achieve powerful speech, a legitimate, known, recognized, authorized and authoritative voice" (Bourdieu 1986: 301) without collectively pooling their voice in an indirect fashion. Indeed, the study of voice reveals that its use by citizens "...depends upon their belief in its expected efficacy" (Dowding et al. 2000: 473) which suggests that analysis must specify the "contextual assumptions" (O'Donnell 1986: 250) of its use and the outcomes it will have. The next section sets out the contextual environment for voice, and reveals that its use by citizens is dependent on and influenced by specific temporal, economic, social and geographical factors that are studied by political ecologists; the 'political ecology of voice.'

\footnotetext{
${ }^{6}$ Individual voice refers to "actions where the intention of the individual in acting is to bring about the desired effect solely through that action." Collective action is "where the intention of the individual in acting is to contribute to the desired effect through that action" (Dowding et. al. 2000: 473), in pursuit of a common goal (Tilly 1978: 7).
} 


\section{The contextual factors that influence citizens exercising voice}

[T] he use of voice can suddenly become a most sought after, fulfilling activity, in fact, the ultimate justification of human existence.. (Hirschman 1981: 215)

While we have established that the functioning and formation of voice depend on the prospects for collective action. A citizen's ability to do this rests partly "upon their legal rights" in their country (Dowding et al. 2000: 473), a reflection that voice can be hazardous where organizations (and the state) make efforts to silence protests (Hirschman 1981: 244). O'Donnell's (1986: 251-252) vertical and horizontal divisions are based on this assumption. The utilization of horizontal voice without major restriction is identified with democratic and non-repressive contexts, also permitting the exercise of collective vertical voice (O'Donnell 1986: 251-252).

The application of environmental voice by citizens is directly affected by the national political environment in which they live and operate, and their "opportunity" to do so (Tilly 1978: 55). "Opportunity describes the relationship between the population's interests and the current state of the world around it" (Tilly 1978: 55) and one can begin to understand this if consideration is given to political freedoms (Sen 2001: 38, 152), and the influence that authoritarian versus democratic states have on voice. In authoritarian countries, extreme regimes will suppress vertical and horizontal voice in order to gain power and stability through the conversion of "...citizens into isolated, wholly private, and narrowly selfcentered individuals" (Hirschman 1992: 82). The former Soviet Union's Great Terror is given as an example by Kuromiya (2008). Meanwhile, in democracies, stronger civic and legal laws protect freedom of speech and dissent, with equality and meaningful participation remaining central to democratic participation (Verba et al. 1995: 1). Thus, "...it is easier to participate in a public protest when one only loses time through the act of participation than when one thereby risks losing one's head" (Hirschman 1982: 4-5). Moreover, the state's political system and societal freedom has a significant impact on the ability of citizens and other actors like NGOs to hold economic actors accountable for pollution. For instance, in Burma, the authoritarian regime's "business as usual" (Bryant 1996) approach to environmental management left people with few options for dissent, and environmental politics was a type of resistance politics (Doyle and Simpson 2006).

The links between voice and political ecology is visible here. The capacity of citizens to voice is based on the retention or (unequal) diffusion of power by the state to particular social groups or actors in society. Consequently, PEV must analyze the wider national political environment in which the environmental pollution is occurring in order to establish the levels of voice permitted by citizens; a democratic country with freedom of speech will tolerate a higher level (or ceiling), Hirschman argues (Hirschman 1981: 224). ${ }^{7}$

A study of voice from this state political perspective also suggests not all EMaDEs are alike. For example, while Latin American countries all "...share a common basis in law, language, history, culture, sociology, colonial experience, and overall political patterns that enable us to discuss the region in general terms", they are different (Wiarda and Kline 2001: 1). There are diverse national laws and regulations, distinct social strata, income levels and opportunity, separate histories and customs etc. in which citizens live and also apply their voice. This is a crucial point. Though events like hydrocarbon conflicts may have similar causes and effects across countries and regions, each case needs to be analyzed in relation to the specific socio-political and economic environment (Vasquez 2014: xvii), a conclusion also applicable to other relevant events like development project outcomes (Ballet and Randrianalijaona 2014: 218). Any investigation into the issues surrounding voice vis-à-vis environmental problems cannot be generalized.

In order for citizens' voice to function effectively, individuals will need to possess reserves of political influence that they can call upon when sufficiently provoked (Hirschman 1970: 70-71). Despite political influence not being a necessary precondition for consumer voice, within the environmental context it would appear to be key for two interlinked reasons. The wider collective scalar impact of environmental problems and the actors involved (a variable combination including international agencies,

\footnotetext{
${ }^{7}$ One must add however that this ceiling will have a limit on the extent of voice and exit as "...there are levels of exit (disintegration) and voice (disruption) beyond which it is impossible for an organisation to exist as an organisation" (Hirschman 1981: 224).
} 
NGOs, national and local government mechanisms, and private industry) highlights that an individual citizen's voice, and its influence, rests to a greater degree on their political influence and ability to engage with these actors. While horizontal voice is seen by some to be far less costly and has the psychological benefit of expressing and sharing (again dependent on the context), vertical voice is more costly and has some psychological costs (the stress of speaking critically to one's superiors), suggesting those with a stronger political influence will stand a greater chance of success (Soete and Weehuizen 2003: 27). Sen argues illiteracy can cause hindrance to political participation (Sen 2001: 39). The instrumental freedom of social opportunity offered by better education, healthcare etc. increases the effective participation in economic and political matters (Sen 2001).

Sociodemographic studies show that the time, effort, and money needed for effective participation are often borne by those with more resources (Dahl 1961: 274) and political confidence (Dahl 1961: 286293), which leaves the most effective interest groups in local politics as high-income and upper-middleclass citizens (Dahl 1961: 273, 282-283; Hirschman 1981: 214; Laurian 2004: 55; Verba et al. 1995: 288303). Sen cautions against making generalised links between income and individual achievements and freedoms, owing to personal social and economic circumstances that impact on the ability of certain citizens to utilize their voice (Sen 2001: 38-39 and ch. 4). ${ }^{8}$

In socially unequal countries (e.g. in Latin America) these issues have particular salience. The level of influence that certain groups and individuals can exert on the authorities and on political decisionmaking depends on a strong voice and position in society and benefiting from the rule of law (Vasquez 2014: 47). Low EMaDEs scores in Transparency International Corruption Perceptions Index rankings indicate a lack of confidence and trust that there ae fair and effective governmental institutions (Vasquez 2014: 47). This may mean less willingness to participate confidently and to seek influence through voice and other methods (Wiarda and Kline 2001: 46-47). ${ }^{9}$

The application of voice by those in a more marginalized societal position becomes extremely difficult. This is particularly true of indigenous and ethnic peoples, that have borne the brunt of European colonization (see Varese 1996) and like other weak/marginalized global citizens are hit hard by the costs of environmental problems (Bryant and Bailey 1997: 40; Reed 2002: 213). Natural resource extraction projects (particularly oil and gas) and possible environmental pollution can often occur in close proximity and in remote locations like the Amazon rainforest. Elite manipulation of the state has serious impacts on equality "...because economically disadvantaged groups lack the tools [such as a strong social position and voice] for accessing the authorities through parallel channels" (Vasquez 2014: 47).

Through PEV, research must extend towards the positon of the citizens affected by pollution, not just through an examination of the national social trends (i.e. level of inequality). Following Sen and others, actual citizen accessibility to voice mechanisms requires more detailed investigation. Laurian (2004: 54) argues that the nature of the problem in her U.S study (the siting of toxic waste sites) and the high-costs of clean-up necessitates the involvement of federal, state, and local government agencies all of which are (at least in theory) "...officially committed to increasing public participation in planning." A similar conclusion is applicable to other environmental problems and the role of various political agencies at different spatial levels; the scale, severity and nature of an environmental problem requires coordinated responses between local, provincial and national government mechanisms and the ability to integrate citizen's voices at each level. However, while democratic states should (theoretically) be able to provide citizens with multiple points of voice accessibility at different spatial scales (local, regional and national levels) and in different formats (community meetings, ICT-methods), it is clear that this is variable in term of geography and across social groups.

In a general sense, authors have noted that EMaDEs lack the ability of the advanced economies to be able to shift resources more quickly into desired areas (Stolper 1966: 205). Education and healthcare involve recurrent costs, and staffing problems set a limit on what can be done, particularly in remoter geographic locations (Stolper 1966: 215 see also Reed 2002: 212). "In the first place, it needs to be restated that [while] space qua space has no casual power and spatial relations of themselves do not produce effects" (Slater 1989: 13), "depending on the nature of the constituents, their spatial relations

\footnotetext{
${ }^{8}$ Dahl (1966: 284) does caution that even though citizens with lower incomes are much less likely to participate in local decisions than citizens with larger incomes, "...there are so many more of them in the first group that a smaller proportion of them can amount to an aggregate greater than the group of participants with larger incomes."

${ }^{9}$ Though this is contested (see Gamson 1968 cited in Laurian 2004: 57).
} 
may make a crucial difference" but only in terms of "the particular casual powers and liabilities constituting it" (Sayer 1985: 52 cited in Slater 1989: 13). A key constituent that influences these spatial relations is the nation state.

The relationship between central decision making mechanisms and those in frontiers or more remotely located territories is a key issue for political ecologists. A key line of investigation is to consider how far the spatial locality of decisions surrounding environmental management or natural resource projects influence voice and participation, as well as citizen access to businesses and their decisionmaking mechanisms or modes of communication.

One can turn back to Hirschman here for initial guidance. The author concluded that certain "strict limits" are placed on citizens regarding their "...involvement in public affairs as certain political institutions [and arguably business] keep them from expressing the full intensity of their feelings" (Hirschman 1982: 103). So whilst firms do not stop a citizen's ability to use voice, they may withhold or control access to key decision making mechanisms, and evidence of this can be seen through two illustrative REI extraction projects. In Peru, environmental regulation sets out the parameters of prior consultation between REIs and indigenous peoples (Regulation, Environmental Protection, Hydrocarbon Activities, DS 015-2006-EM in Powers 2012: 8). However, a study of the Perina Project (a large open-pit gold mine in the Peruvian Amazon owned and operated by Barrick Gold Corporation of Canada), shows how the "neoliberalisation of resource governance" has seen the production of:

...new spatial relations of governance at the point of extraction; the community relations office, now a critical node of decision-making regarding the livelihood impacts of mining in adjacent communities, is located on mine property, behind a closely guarded gate. (Himley 2008: 446)

It is clear that the firm and not the state administers access to a crucial site for decision-making, and the capacity to do so is enabled by private property rights. Similarly, in Madagascar, the QMM mining project saw criticism over the low levels of local population involvement in the project in the late 1980s, and a restricted participatory process that did not necessarily represent diverse societal opinions (Ballet and Randrianalijoana 2014: 222).

What can we conclude from these two brief examples? REI decision making mechanisms have been key practical problems for firms (Reed 2002: 220). Historically, Indigenous peoples and ethnic minorities have lacked effective participation in decision-making. Reed argues that while firms are willing to consult with local communities, to take their concerns into consideration and possibly modify their plans, they are not willing to include local communities into decision-making mechanisms or to consider the possibility that local community desires might take precedence over those of the REIs, a process termed "decoupling" (Backer 2007: 33-34; Reed 2002: 221 my italics. See also Cragg and Greenbaum 2002).

Part of the problem is that capitalist firms seek to maximize profit and to reduce costs (some of which are incurred by protests, and shareholder actions) (Reed 2002: 222). They will consider the costs and benefits of various actors (e.g. local citizens, NGOs, financiers like shareholders, banks, multilateral lending agencies) but ignore the interests (and voices) of some while paying attention to others (Kapelus 2002: 291). This leaves local participants relying on the conscience of corporations to respond to concerns as moral demands, which can instead often see firms seek to quell voice through special favors (Hirschman 1981: 240-241), violent suppression or the funding of alternative movements (Rowell 1996). Non-state economic actors are able to control and manage the parameters of voice for citizens (where, when, how, their frequency of contact) regardless of the wider state environment in which people reside.

A more accurate depiction of the relevant economic actors in question is important, especially if these are private businesses, and this can be illustrated for oil companies. Vasquez (2014: 123-124) has suggested that each have their own unique operating styles which differ "...greatly in the way they incorporate environmental and social safeguards and on the degree of significance they grant to these." Through their more secure financial position larger REIs have more investment in corporate social responsibility (CSR) and larger professional teams of community relations specialists (Vasquez 2014: 124-127). So the level, accessibility and therefore strength of citizen voices will be different depending on the REI. The type of REI impacts upon voice and accessibility (see Figure 3) and this is a starting point 
for investigation of their social effects. A similar process can also be conducted for other economic actors, including a pervasive force in Latin America, mining companies.

\begin{tabular}{|c|c|c|}
\hline $\begin{array}{l}\text { Size of REI operations } \\
\text { (based on number of } \\
\text { individual and shared } \\
\text { operations with other private } \\
\text { and state owned REIs). This } \\
\text { encompasses oil and gas } \\
\text { operations }\end{array}$ & $\begin{array}{c}\text { Privately operated REIs } \\
\text { (majority stake owned by private } \\
\text { business interests) } \\
\text { Term in italics }\end{array}$ & $\begin{array}{c}\text { State run REIs } \\
\text { (majority stake owned by } \\
\text { nation(s) } \\
\text { Term in italics }\end{array}$ \\
\hline $\begin{array}{lrr}\text { International } & \text { (or } & \text { trans- } \\
\text { national): } & \text { REIs } & \text { with } \\
\text { single/shared } & & \text { business } \\
\text { operations in at least thirty } \\
\text { countries }\end{array}$ & $\begin{array}{l}\text { "Trans national } \\
\text { extraction industries" } \\
\text { (TNREIs) } \\
\text { e.g. BP, ConocoPhillips, Exon, } \\
\text { Mobil, Royal Dutch Shell, Total }\end{array}$ & $\begin{array}{l}\text { "State owned trans national } \\
\text { resource extraction industries" } \\
\text { (SOTNREIs) e.g. China National } \\
\text { Petroleum Corporation }\end{array}$ \\
\hline $\begin{array}{l}\text { Regional: } \text { REIs with } \\
\text { international single/shared } \\
\text { operations focused in less } \\
\text { than thirty countries }\end{array}$ & $\begin{array}{l}\text { "Regional resource extraction } \\
\text { industries" (RREIs) e.g. Chevron, } \\
\text { Hunt Oil Company, Premier Oil } \\
\text { Company, Tullow Oil }\end{array}$ & $\begin{array}{l}\text { "State owned regional resource } \\
\text { extraction industries" (SORREIs) } \\
\text { e.g. Petrobas (Brazil), Pluspetrol } \\
\text { (Argentina), Sinopec Corps } \\
\text { (China) }\end{array}$ \\
\hline $\begin{array}{l}\text { National/ local: REIs with } \\
\text { individual/shared } \\
\text { in a single country }\end{array}$ & $\begin{array}{l}\text { "National resource extraction } \\
\text { industries" (NREIs); }\end{array}$ & $\begin{array}{l}\text { "State owned national resource } \\
\text { extraction industries" (SONREIs) } \\
\text { e.g. Gazprom (Russia), Pemex } \\
\text { (Mexico), Saudi Aramco (Saudi } \\
\text { Arabia), Petroperu (Peru) }\end{array}$ \\
\hline
\end{tabular}

Figure 3: Typology of resource extraction industries (REI).

Lastly, and interlinked to all of these points is the fact that voice changes over time (see Corbin and Strauss 1990: 5), as Hirschman's original focus on the consumer-industry relationship did recognize (see Pitt et al. 2002). Changes in national political environments, e.g. the weakening of an authoritarian regime, will open up previously unavailable choices for citizens through their new-found rights, increasing the likelihood of vocal behavior (Hirschman 1995: 14). Social position, economic wealth and opportunity can change over the life course, depending on the context. Similarly, the interactions between economic actors and citizens will change dependent on new business laws and regulations on consultation, and changes in shareholder aims and values. Again, the links between voice and political ecology concerns are noticeable. Analysis of voice at one temporal moment will only provide a 'snapshot' on citizen voice at that time. Other variables also change. The work of the 'present' must be situated and related to the past.

\section{Radical and collective voice}

Understanding of history also leads citizens to deploy what they feel are the most effective methods to utilize in pursuing their goals, environmental or otherwise. Two broad types of voice actions require mention. The first is 'radical voice' such as demonstrations, riots and revolutions, categorized by Hirschman (1971: 5-6) as "participatory explosions" for "which there are no parallels." Zuindeau's (2009: 158) research underscores how different forms and levels of violence encompass voice actions which Herring's inherency theory suggests are taken when some political challengers (e.g. marginalized groups) are denied access to the privileges and advantages available to others (Herring 1989: 139). The use of violence will greatly increase the likelihood that the event will be noticed, which may help efforts to force through changes (Tilly 1978: 92). One can see an illustration of this in Bolivia where the 2000 'Water War' and 2003 'Gas War' saw protestors reject the restructuring and re-scaling of resource governance 
under recent neoliberal reforms. Through protests, blockades and resistance they sought procedural and distributive justice (Perreault 2006).

A study of these events, or "critical moments" (Khan 2013) can help to reveal the causes of these actions. In Latin America for instance, the failure to strengthen the democratic system and to create a strong and equitable state presence has set limits on open participation for self-expression. This has prevented violence and other radical means being used as a way to voice grievances or to seek justice (Berkman 2007: 8; Vasquez 2014: 53-54). People are not violent because they are poor, but rather because the long-term segregation within "neighborhoods of concentrated poverty" and across generations causes people to adapt to conditions of deprivation that see them "come to rely on violence as a basic tool for survival" (Sanchez 2006: 181).

Radical voice is not confined to marginalised social groups. Violence and resistance is generally a last resort for people whose peaceful attempts at redress are frustrated or ignored (Zahar 2006: 50) (an issue that is more acute for citizens in authoritarian countries), an example of which can be seen in the 1996 citizen's rebellion in the Mexican town of Tepotzlan over the imposition of top-down 'development' by unresponsive elected officials and developers (Simon 1998). Still, for peripheral and mainstream social groups, care must be taken in the application of radical voice as "...people might forget their deferential obligations and let voice get carried away" which may hinder long term efforts at securing a particular goal where less flexible vertical political mechanisms frustrate grassroots interests (Adelman 2013: 443).

This leads neatly into the second type of voice action. Collective voice can go some way to combating the difficulties that disadvantaged groups, those without influence or those forced to use violence, can face in their consultations with government and other economic actors. Where there is environmental pollution resulting from resource extraction, one can differentiate "...between groups [or stakeholders] that have a legal, moral or presumed claim on the firm and groups that have an ability to influence the firm's behaviour, direction, process, or outcomes" (Mitchell et al. 1997: 859). The former include citizens with a local or direct 'stake' in the issue or event, and supportive community based organisations (Bourdieu 1986: 301). The latter include local, national or international NGOs and other global citizens (who are perhaps connected to a campaign run by the NGO) with a range of objectives (e.g. environmental protection, human rights) that lead them to lobby REIs and business actors. These are different 'voices' but interconnected.

Vasquez's (2014: 90) research found "...that a unified indigenous voice usually allows for a faster resolution of oil and gas conflicts", able to use the prevailing sociopolitical climate to its advantage. A global network of collective voice actors now operate with a focus on redress for environmental issues (Kapelus 2002: 277), supporting communities through their international presence (Lipschutz 1997: 9091). Their ability to mobilise communities at the grass-roots level is important, especially in locations where there are unequal power relations between communities and other actors (see for example Boele et al. 2001: 83) while their capacity to also work closely with business can help to ensure they utilise more responsible environmental behaviour (Reed 2002: 207). Celebrities and other high profile individuals can also lend their weight to environmental campaigns in an effort to strengthen local collective voice (Brosius 2006).

In some situations, local citizens risk becoming "dispossessed" of their own voice, "...deprived of an expression which specifically expresses" themselves and their own interests which are "...denied and annulled, by the common voice, the opinion communis as produced and uttered by the accredited spokesperson" (Bourdieu 1986: 301-302). Thus, whilst political parties have been seen as offering the best means for societally excluded citizens to have their interests heard, parties can cater predominantly to elite interests (Stiefel and Wolf 1994: 139-140).

Within groups, a campaign can also cater to elites as Hirschman notes (Hirschman 1981:242-243). He typifies this as the "treachery of voice" where changes achieved through voice are primarily in the interests of the few, a factor which may constrain individuals from participating in collective voice situations (1981: 244). Communities must be able to hold NGOs and their other supporters accountable but downward accountability can be weak, for example when the NGO pursues a technical campaign strategy unfamiliar to local actors (Ebrahim 2003; Kamat 2004: 167).

Through applying PEV, the possibilities for, and strength of individual citizen voice can be investigated. This is a good starting point from which the political ecology of a struggle or a campaign may be understood in context and in relation to cause(s) of these actions. For example is it driven by social position or structural flaws in the state system? A range of real-world contextual influences on voice are placed together in Figure 4. Each of these requires investigation in order to build up a strong assessment of the use of voice and the potential barriers that may be faced by various stakeholders in their efforts at holding economic actors accountable for pollution problems. 


\begin{tabular}{|c|}
\hline The theoretical rationale \\
for applying voice to \\
environmental problems \\
-Citizens willing to voice to \\
defend their own quality of life. \\
-Loyalty (to a territory) will \\
hold exit at bay and activate \\
voice. This is influenced by a \\
person's time horizons e.g. they \\
won't immediately exit, to give \\
time for a solution. \\
-Public interest problems (like \\
pollution) will see voice benefit \\
some people at some times that \\
help outweigh the individual \\
cost (in time, effort, money) of \\
deploying it. \\
voice. \\
- The solutions to environmental \\
problems generally occur \\
through vertical political \\
settings which are most \\
successfully influenced through \\
collective voice. Environmental \\
pollution impacts a collective \\
(variably sized) group of \\
citizens creating a collective \\
voice
\end{tabular}

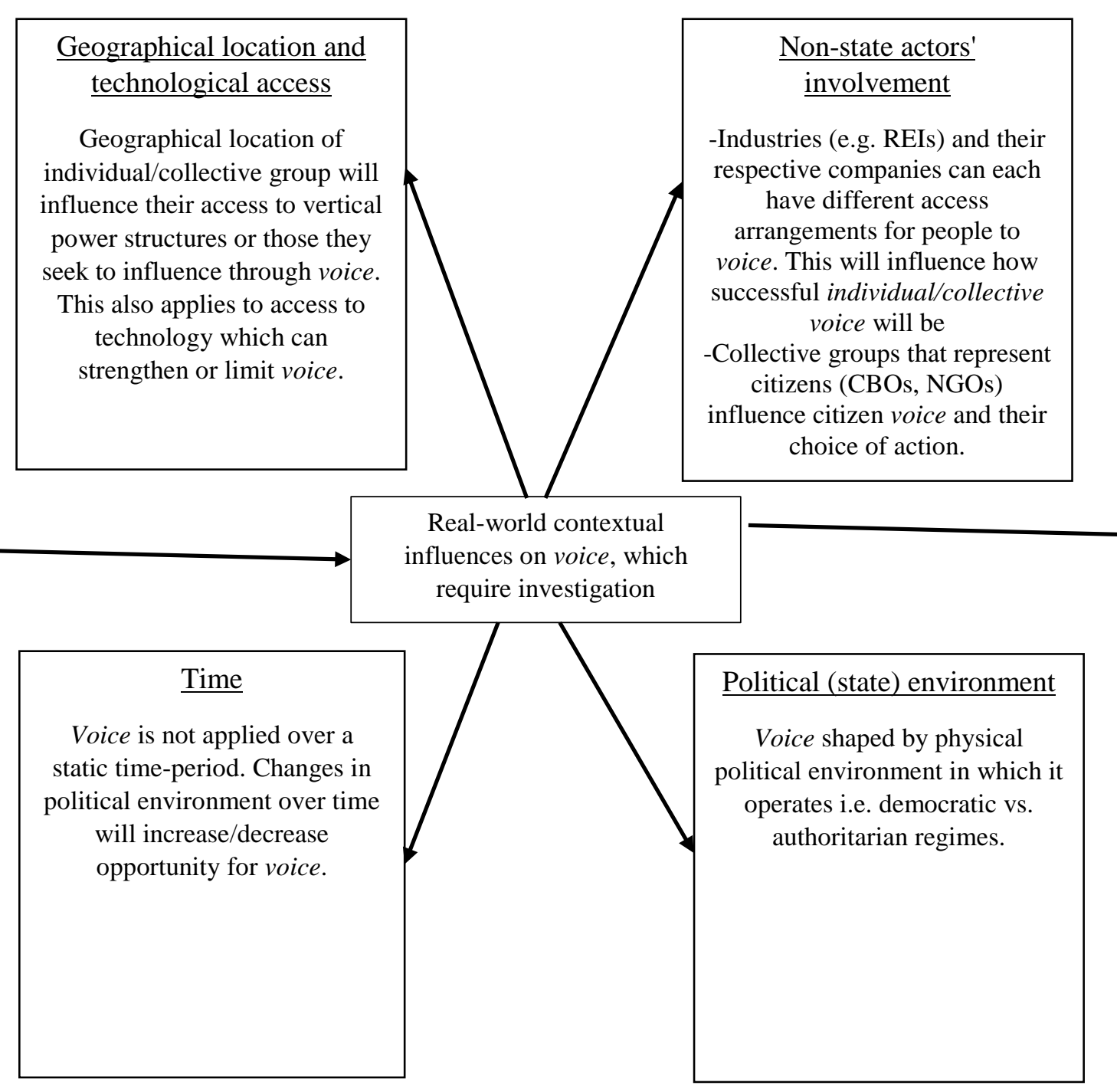

\section{Socio-economic and racial influences}

-The stronger a person's societal position and ability to meet participatory costs (time, effort, money), the stronger their ability to voice, and their access and influence. This means that marginalised citizens (e.g. indigenous groups or ethnic minorities) who are in lower social positions will often have a weaker voice and may face difficulties meeting costs of participation. These problems are accentuated in socially unequal countries.

-The higher an individual's level of political influence, the greater their chance of success in vertical voice situations. 


\section{Conclusion: applying voice to an environmental problem}

This article has shown that Hirschman's theory of exit and voice has an important role to play in relation to understanding responses to environmental pollution. The study of voice is a truly multi-faceted process and one that offers strong integration into political ecology's efforts to understand the causes and possible solutions to environmental degradation. Through PEV, researchers can explore the temporally specific economic, social, and geographical environment in which various stakeholders are able to operate and use their voice. This can be applied to a specific case and its context. Stakeholder voice has been shown to be influenced by power relations in various relationships (state-citizens, businesses-citizens, $\mathrm{CBO} / \mathrm{NGO}$-states, $\mathrm{CBO} / \mathrm{NGO}$-citizens, CBO/NGOs-business) and is linked to the control of, and thus access to, decision-making mechanisms. Crucially, these relationships surrounding access are influenced not only by the wider macro-political environment but also more localized power relationships involving firms which have the greatest power in dictating the scope and frequency of consultations with citizens and other non-state stakeholders.

Access to decision-making mechanisms is also linked to spatial scale and locality, and the type of voice mechanism utilized by the state and business actors. These have a significant bearing on stakeholder trust, their willingness to participate, and the type of voice action they utilize. The study of voice requires a focus on these macro and micro influences. The political ecology of voice offers an innovative angle from which to view the responses made to significant environmental issues and problems.

\section{References}

Adelman, J. 2013. World philosopher: the odyssey of Albert. O. Hirschman. Princeton, NJ: Princeton University Press.

Agrawal, A. and Gibson, C.C. 1999. Enchantment and disenchantment: the role of community in natural resource conservation. World Development 27(4):629-649.

Andersson, K.P. 2004. Who talks with whom? The role of repeated interactions in decentralized forest governance. World Development 32(2):233-249.

Backer, L. 2007. Engaging stakeholders in corporate environmental governance. Business and Society Review 112(1): 29-54.

Ballet, J. and Randrianalijaona, M. 2014. A case study on human development and security: Madagascar's mining sector and conservation-induced displacement of populations. Journal of Global Ethics 10(2): 216-230.

Barry, B. 1974. Exit, voice, and loyalty: responses to decline in firms, organisation, and Hirschman. British Journal of Political Science 4(1): 79-107.

Barry, J. and Randrianlijaona, M. 2006. Resistance is fertile: from environmental to sustainability citizenship. In Dobson, A. and Bell, D. (eds.) Environmental citizenship. Cambridge, Massachusetts: The MIT Press. Pp. 21-48.

Batterbury, S.P.J. 2015. Doing political ecology inside and outside the academy. In. Bryant R.L. (ed.) The international handbook of political ecology. Cheltenham, UK: Edward Elgar. Pp.27-43.

Batterbury, S.P.J. and Bebbington, A.J. 1999. Environmental histories, access to resources and landscape change: an introduction. Land Degradation and Development 10(4): 279-289.

Bebbington, A.J., Bornschleql, and Johnson, A. 2013. Political economies of extractive industry: from documenting complexity to informing current debates. Development and Change DOI: 10.1111/dech.12057 (virtual issue introduction)

Berkman, H. 2007. Social exclusion and violence in Latin America and the Caribbean. Inter-American Development Bank. Working Paper 613. [accessed 26 November 2015]. http://www.iadb.org/res/publications/pubfiles/pubwp-613.pdf

Berglund, E. 2006. Ecopolitics through ethnography: the cultures of Finland's forest-nature. In Biersack, A. and Greenberg, J.B. (eds.) Reimagining Political Ecology. Durham NC: Duke University Press. Pp.97-120.

Biersack, A. 1999. Introduction: from the 'new ecology' to the new ecologies. American Anthropologist 101(1): 5-18. 
Birch, A. H. 1974. Economic models in political science: the case of exit, voice, and loyalty. British Journal of Political Science 5(1): 69-82.

Bixler, R.P., Dell'Angelo, J., Mfune, O. and Roba, H. 2015. The political ecology of participatory conservation: institutions and discourse. Journal of Political Ecology 22: 164-182.

Blaikie, P. 1985. The political economy of soil erosion in developing countries. New York: Longman.

Blaikie, P. and Brookfield, H.C. 1987a. Defining and debating the problem. In Blaikie, P. and Brookfield, H.C. Land degradation and society. London and New York: Routledge. Pp.1-26.

Blaikie, P. and Brookfield, H.C. 1987b. Approaches to the study of land degradation. In Blaikie, P. and Brookfield, H.C. Land degradation and society. London and New York: Routledge. Pp. 27-48.

Bluhdorn, I. and Welsh, I. 2007. Eco-politics beyond the paradigm of sustainability: a conceptual framework and research agenda. Environmental Politics 16(2):185-205.

Boele, R., Fabig, H. and Wheeler, D. 2001. Shell, Nigeria and the Ogoni. A study in unsustainable development: I. The story of Shell, Nigeria and the Ogoni people - environment, economy, relationships: conflict and prospects for resolution. Sustainable Development 9(2): 74-86.

Boelens, R., Getches, D. H. and Guevara-Gi, J. A. 2010. Out of the mainstream: water rights, politics and identity. London, Washington, DC: Earthscan.

Bourdieu, P. 1986. The antinomies of collective voice. In Foxley, A., McPherson, M. S., O'Donnell, G. A., and Hirschman, A. O. (eds.) Development, democracy, and the art of trespassing: essays in honor of Albert O. Hirschman. Notre Dame, IN: University of Notre Dame Press. Pp.301-302.

Bridge, G. 2011. Past peak oil: political economy of energy crises. In Peet, R., Robbins, P., and Watts, M.J. (eds.) Global political ecology. London: Routledge. Pp.307-324.

Bridge, G., McCarthy, J. and Perreault. T. 2015. Editors Introduction. In Perreault, T., Bridge, G and McCarthy, J. (eds.) The Routledge handbook of political ecology. London and New York: Routledge. Pp.3-18.

Brosius, J.P. 2006. Between politics and poetics: narratives of dispossession in Sarawak, East Malaysia. In Biersack, A. and Greenberg, J. B. (eds.) Reimagining political ecology. Durham \& London: Duke University Press. Pp.281-322.

Broto, V.C. 2013. Employment, environmental pollution and working class life in Tuzla, Bosnia and Herzegovina. Journal of Political Ecology 20: 1-13.

Bryant R.L. (ed.) 2015a. The international handbook of political ecology. Edward Elgar Publishing: Cheltenham, UK.

Bryant, R.L. 2015b. Reflecting on political ecology. In Bryant R. L. (ed.) The international handbook of political ecology. Edward Elgar Publishing: Cheltenham, UK. Pp. 14-24.

Bryant, R.L. 1998. Power, knowledge and political ecology in the third world: a review. Progress in Physical Geography 22(1): 79-94.

Bryant, R.L. 1996. The greening of Burma: political rhetoric or sustainable development? Pacific Affairs 69(3): 341-359.

Bryant, R.L. 1992. Political ecology: an emerging research agenda in the third world. Political Geography 11(1):12-36.

Bryant, R.L, and Bailey, S. 1997. Third world political ecology. London: Routledge.

Bullard. R.D. 1993 Confronting environmental racism: voices from the grassroots. Boston, Mass.: South End Press.

Cleveland, C.J. 2007. Energy transitions past and future. In Encyclopaedia of Earth. Washington, D.C: Environmental Information Coalition, National Council for Science and the Environment.

Corbin, J. and Strauss, A. 1990. Grounded theory research: procedures, canons, and evaluative criteria. Qualitative Sociology 13(1): 3-21.

Cragg, W. and Greenbaum, A. 2002. Reasoning about responsibilities: mining company managers on what stakeholders are owed. Journal of Business Ethics 39(3): 319-335.

Dahl, R. 1961. Who governs? Democracy and power in an American city. New Haven and London: Yale University Press. 
Davis, D.K. 2015. Historical approaches to political ecology. In Perreault, T., Bridge, G., and McCarthy, J. (eds.) The Routledge handbook of political ecology. Abingdon, Oxon: Routledge. Pp. 263-276.

Dobson, A. and Bell, B. 2006. Introduction. In Dobson, A. and Bell, D. (eds.) Environmental citizenship. Cambridge, Massachusetts and London, England: The MIT Press. Pp. 1-18.

Dowding, K., John, P., Mergoupis, T., and Van Vugt, M. 2000. Exit, voice and loyalty: analytic and empiric development. European Journal of Political Research 37(4): 469-495.

Doyle, T. and Simpson, A. 2006. Traversing more than speed bumps: green politics under authoritarian regimes in Burma and Iran. Environmental Politics 15(5): 750-767.

Ebrahim, A. 2003. Accountability in practice: mechanisms for NGOs. World Development 31(5): 813-29.

Flew, T. 2009. The citizen's voice: Albert Hirschman's exit, voice and loyalty and its contribution to media citizenship debates. Media, Culture and Society 31(6): 977-994.

Forsyth, T. (2003) Critical political ecology: the politics of environmental science. Routledge: London, New York.

Gamson, W.A. 1968. Power and discontent. Homewood, IL: Dorsey.

Graham, J.W. and Keeley, M. 1992. Hirschman's loyalty construct. Employee Responsibilities and Rights Journal 5(3): 191-200.

Greenberg, J.B. 2006. The political ecology of fisheries in the upper Gulf of California. In Biersack, A. and Greenberg, J.B. (eds.) Reimagining political ecology. Durham NC: Duke University Press. Pp.121-148.

Groves, C. 2015. The bomb in my backyard, the serpent in my house: environmental justice, risk, and the colonialization of attachment. Environmental Politics 24(6): 853-873.

Himley, M. 2008. Geographies of environmental governance: the nexus of nature and neoliberalism. Geography Compass 2(2): 433-451.

Hinojosa, L., Bebbington, A.J., Cortez, G., Chumacero, J.P., Humphreys-Bebbington, D. and Hennermann, K. 2015. Gas and development: rural territorial dynamics in Tarija, Bolivia. World Development 73: 105-117.

Hirschman, A.O. 1970. Exit, voice, and loyalty. Cambridge, Mass: Harvard University Press. Ch.8

Hirschman, A.O. 1978. Exit, voice, and the state. World Politics 31(1): 90-107.

Hirschman, A.O. 1981. Essays in trespassing: economics to politics and beyond. Cambridge: Cambridge University Press.

Hirschman, A.O. 1982. Shifting involvements: private interest and public action. Oxford: Martin Robertson.

Hirschman, A.O. 1992. Rival views of market society and other recent essays. New York: Viking/Penguin

Hirschman, A.O. 1995. A propensity to self-subversion. Cambridge, Massachusetts, and London, England: Harvard University Press.

Horton, D. 2006. Demonstrating environmental citizenship? A study of everyday life among green activists. In Dobson A. and Bell, D. (eds.) Environmental citizenship. MIT Press; Cambridge, Massachusetts. Pp.127-150.

Hvalkof, S. 2006. Progress of the victims: political ecology in the Peruvian Amazon. In Blaikie, P.M. and Brookfield, H.C. Land degradation and society. Routledge: London and New York. Pp.195-232.

Ioris, A.A.R. 2014. The political ecology of the state: the basis and evolution of environmental statehood. London and New York: Routledge.

Ioris, A.A.R. 2011. Book review of 'Global political ecology'. Scottish Geographic Journal 127(3): 253254.

Kamat, S. 2004. The privatization of public interest: theorizing NGO discourse in a neoliberal era. Review of International Political Economy 11(1): 155-176.

Kapelus. P. 2002. Mining, corporate social responsibility and the "community": the case of Rio Tinto, Richards Bay Minerals and the Mbonambi. Journal of Business Ethics 39(3): 275-296.

Karlsson, B.G. 2011. Unruly hills: a political ecology of India's northeast. New York, Oxford: Berghahn Books. 
Khan, M.T. 2013. Theoretical frameworks in political ecology and participatory nature/forest conservation: the necessity for a heterodox approach and the critical moment. Journal of Political Ecology 20: 460-472.

Kuromiya. H. 2008. The voices of the dead: Stalin's great terror in the 1930s. New Haven: Yale University Press.

Laurian, L. 2004. Public participation in environmental decision making: findings from communities facing toxic waste cleanup. Journal of the American Planning Association 70(1): 53-65.

Le Meur, P.-Y., Horowitz, L. and Mennesson, T. 2013. Horizontal" and "vertical" diffusion: the cumulative influence of impact and benefit agreements (IBAs) on mining policy-production in New Caledonia. Resources Policy 38(4): 648-656.

Lindell, I. 2010. Between exit and voice: informality and the spaces of popular agency. African Studies Quarterly 11(2-3): 1-11.

Lipschutz, R.D. 1997. From place to planet: local knowledge and global environmental governance. Global Governance 3(1): 83-102.

Lucero, J.A. 2008. Struggles of voice: the politics of indigenous representation in the Andes. Pittsburgh, PA: University of Pittsburgh Press.

Martinez-Alier, J. 2004. Ecological distribution conflicts and indicators of sustainability. International Journal of Political Economy 34(1):13-30.

M'Gonigle, R.M. 1999. Ecological economic and political ecology: towards a necessary synthesis. Ecological Economics 28(1): 11-26.

Mitchell, R.K., Agle. B.R., and Wood, D.J. 1997. The theory of stakeholder identification and salience: defining the principle of who and what really counts. The Academy of Management Review 22(4): 853-886.

Moore, D.S. 1998. Subaltern struggles and the politics of place: remapping resistance in Zimbabwe's eastern highlands. Cultural Anthropology 13(3): 344-381.

Najam, A. 1996. NGO accountability: a conceptual framework. Development Policy Review 14: 339353.

Nash, N. and Lewis, A. 2006. Overcoming obstacles to ecological citizenship: the dominant social paradigm and local environmentalism. In Dobson, A. and Bell, D. (eds.) Environmental citizenship. Cambridge, Massachusetts: MIT Press. Pp.153-184

Neumann, R.P. 2005. Making political ecology. London: Hodder Arnold.

O'Donnell, G. 1986. On the fruitful convergences of Hirschman's exit, voice, and loyalty and shifting involvements: reflections from the recent Argentine experience. In Foxley, A., McPherson, M.S., O'Donnell, G.A., and Hirschman, A.O. (eds.) Development, democracy, and the art of trespassing: essays in honor of Albert O. Hirschman. Notre Dame, IN: University of Notre Dame Press. Pp.249-268.

O'Dwyer, B. and Unerman, J. 2010. Enhancing the role of accountability in promoting the rights of beneficiaries of development NGOs. Accounting and Business Research 40(5): 451-471. $\underline{\mathrm{draft}}$

Peet, R., Robbins, P., and Watts, M.J. (eds.) 2011. Global political ecology. Abingdon, Oxon: Routledge.

Perreault, T. 2006. From the Guerra Del Agua to the Guerra Del Gas: resource governance, neoliberalism and popular protest in Bolivia. Antipode 38(1): 150-172.

Perreault, T., Bridge, G., and McCarthy, J. (2015) The Routledge handbook of political ecology. Abingdon, Oxon: Routledge.

Picciotto, R. 2015. Hirschman's ideas as evaluation tools. Journal of MultiDisciplinary Evaluation 11(24):1-11.

Pitt, L.F., Berthon, P.R., Watson, R.T., and Zinkhan, G.H. 2002. The internet and the birth of real consumer power. Business Horizons 45(4): 7-14.

Powers, B. 2012. Best practices: design of oil and gas projects in tropical forests. $2^{\text {nd }}$ edition. E-Tech International. [accessed February 25 2015]. http://www.etechinternational.org/s/ETech2012_BestPracticesHydrocarbonProjects.pdf.

Ramana, M.V. 2013. Nuclear policy responses to Fukushima: exit, voice, and loyalty. Bulletin of the Atomic Scientists 69(2): 66-76. 
Ravnborg, H.M. and Gomez, L.I. 2015. The importance of inequality for natural resource governance: evidence from two Nicaraguan territories. World Development 73: 72-84.

Reed, D. 2002. Resource extraction industries in developing countries. Journal of Business Ethics 39(3): 199-226.

Rousseau. J-J. 2012. Of the social contract and other political writings. Translated by Quintin Hoare. London: Penguin.

Rowell, A. 1996. Green backlash. Global subversion of the environment. London: Routledge.

Sanchez, R. 1996. Insecurity and violence as a new power relation in Latin America. The Annals of the American Academy of Political and Social Science 606: 178-195.

Sayer, A. 1985. The difference that space makes. In Gregory, D. and Urry, J. (eds.) Social relations and spatial structure. London: Macmillan. Pp.49-66.

Sen, A. 2001. Development as freedom. Oxford: Oxford University Press.

Silvern. S.E. 1999. Scales of justice: law, American Indian treaty rights and the political construction of scale. Political Geography 18(6): 639-668.

Simon, D. 1998. Rethinking (post)modernism, postcolonialism, and posttraditionalism: south-north perspectives. Environment and Planning D: Society and Space 16(2): 219-245.

Slater, D. 1989. Territory and state power in Latin America: the Peruvian case. Basingstoke, Hampshire and London: Macmillan.

Smith, M.J. 1998. Ecologism: towards ecological citizenship. Buckingham: Open University Press.

Soete, L. and Weehuizen, R. 2003. No exit: a voice for globelics? Reflections on research on global governance. Globelics Conference, Rio de Janeiro, November 2-6. [accessed 24 February 2015]. https://smartech.gatech.edu/handle/1853/43189.

Stiefel, M. and Wolfe, M. 1994. A voice for the excluded: popular participation in development, utopia or necessity? London: United Nations Research Institute for Social Development.

Stolper, W.F. 1966. Planning without facts: lessons in resource allocation from Nigeria's development. Cambridge, Mass: Harvard University Press.

Tilly, C. 1978. From mobilisation to revolution. First Ed. New York: Newberry Award Records, Inc.

Transparency International. 2014. Corruption Perceptions Index. [accessed 25 February 2015]. http://www.transparency.org/research/cpi/overview.

United Nations. 2007. United Nations declaration on the rights of indigenous peoples. [accessed February 24

2015].

http://undesadspd.org/indigenouspeoples/declarationontherightsofindigenouspeoples.aspx

United Nations Mandate on Human Rights and the Environment. no date. [accessed 24 February 2015]. http://ieenvironment.org/un-mandate/.

United Nations Environment Programme (UNEP). 1972. United Nations conference on the human

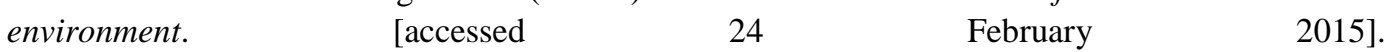
http://www.unep.org/Documents.Multilingual/Default.asp?documentid=97\&articleid=1503.

Varese, S. 1996. The new environmentalist movement of Latin American indigenous people. In Brush, S.B. and Stabinsky, D. (eds.) Indigenous people and intellectual property rights. Washington: Island Press. Pp.122-142.

Vasquez, P.I. 2014. Oil sparks in the Amazon: local conflicts, indigenous populations, and natural resources. Athens and London: The University of Georgia Press.

Verba, S., Schlozman, K.L., and Brady, H.E. 1995. Voice and equality: civic voluntarism in American politics. Cambridge, MA: Harvard University Press.

Watts, M.J. 2015. Now and then: the origins of political ecology and the rebirth of adaptation as a form of thought. In Perreault, T., Bridge, G. and McCarthy, J. (eds.) The Routledge handbook of political ecology. Abingdon, Oxon: Routledge. Pp. 19-50.

Watts, M.J. 2000. Political ecology. In Sheppard, E. and Barnes, T. (eds.) A companion to economic geography. Oxford, Blackwell. Pp: 257-274.

Wiarda, H.J. and Kline, H.F. 2001. An introduction to Latin American politics and development. Boulder, Colorado: Westview Press. 
Zahar, M-J. 2006. Political violence in peace processes: voice, exit, and loyalty in the post-accord period. In Darby, J. (ed) Violence and reconstruction. Notre Dame, Indiana: University of Notre Dame Press. Pp.33-51.

Zimmerer, K.S. and Bassett, T.J. 2003. Approaching political ecology: society, nature, and scale in human-environmental studies. In Zimmerer, K.S. and Bassett, T.J. (eds.) Political ecology: an integrative approach to geography and environment-development studies. The Guilford Press: New York. Pp. 1-28.

Zimmerman, M. and Rappaport, J. 1988. Citizen participation, perceived control, and psychological empowerment. American Journal of Community Psychology 16(5): 725-750.

Zuindeau, B. 2009. Responding to environmental risks: what can Albert Hirschman contribute? Ecological Economics 69(1): 155-165. 